\title{
Morphometry of eggs and immatures of Culex (Culex) saltanensis Dyar (Diptera, Culicidae) obtained in the laboratory and on the field
}

\author{
João A. C. Zequi ${ }^{1} \&$ José Lopes ${ }^{2}$ \\ ${ }^{1}$ Departamento de Agronomia, Universidade Estadual de Londrina. Rua Alagoas 2050, 86020-340 Londrina, Paraná, Brail. \\ E-mail: biologia@unifil.br \\ ${ }^{2}$ Departamento de Biologia Animal e Vegetal, Universidade Estadual de Londrina. Caixa Postal 6001, 86051-970 Londrina, \\ Paraná, Brasil. E-mail: jea@uel.br
}

\begin{abstract}
The objectives of this morphometric study of Culex (Culex) saltanensis Dyar, 1928 larvae were to observe the continuous growth of siphon and cephalic capsule length and width in each instar, and to propose a linear equation to differentiate instars according to the size of both structures. Larvae obtained in laboratory at $27 \pm 11^{\circ} \mathrm{C}$, photoperiod 14L:12D were studied. Larvae of the forth instar were collected on the field and compared with same instar larvae reared in the laboratory. Egg size and pigmentation pattern, first instar continuous growth, and differentiation of larval stages measurements were studied. Egg pigmentation patterns and the shapes of raft eggs differentiated specimens of C. saltanensis from Culex (Culex) quinquefasciatus Say, 1823 found in polluted pond water.
\end{abstract}

KEY WORDS. Instar; larva; measurement.

\begin{abstract}
RESUMO. Morfometria de ovos e imaturos de Culex (Culex) saltanensis Dyar (Diptera, Culicidae) obtidos em laboratório e campo. O objetivo dessa pesquisa foi realizar um estudo morfométrico de largura e comprimento de cápsula cefálica e de sifão em imaturos de Culex (Culex) saltanensis Dyar, 1928 para observar a existência de crescimento da larva sem troca de exúvia e propor uma equação linear para separação dos diferentes instares através do tamanho dessas estruturas. Os estudos morfométricos foram realizados em imaturos que tiveram desenvolvimento em laboratório a $27 \pm 1^{\circ} \mathrm{C}$ e fotoperíodo 14L:10E. Também coletou-se larvas de quarto instar no campo, para comparação com as do mesmo instar criadas em laboratório. O tamanho do ovo e o padrão de pigmentação também foi pesquisado. Verificou-se crescimento contínuo no primeiro instar, e foi possível separar os estádios larvais através das mensurações realizadas. Através do padrão de pigmentação e formato das jangadas de ovos, foi possível separar C. saltanensis de Culex (Culex) quinquefasciatus, Say, 1823 os quais coabitam em lagoas com água poluída.
\end{abstract}

PALAVRAS-CHAVE. Instar; larva; medida.

Culex (Culex) saltanensis Dyar, 1928, a mosquito that can be infected with Plasmodium cathemerium Hartman, 1927, is the primary vector of Plasmodium juxtanucleare Versiani \& Gomes, 1941 (Lourenço-de-Oliveira \& Castro 1991). Sibajev et al. (1993) described the trypanosomal species Crithidia ricardoi, which was isolated from C. saltanensis. This mosquito is typical of neotropical areas and can be found in northern Paraná, Brazil. Its larvae are found in industrial effluents and sewer sedimentation treatment ponds, and in manufactured breeding sites, competing with Culex (Culex) quinquefasciatus Say, 1823 (LOPES 1997a).

Culex saltanensis and eight other species of Culicidae, were first found in the state of Rio de Janeiro by LOURENÇO-DE-OLIVEIRA (1984). In Entre Rios and Corrientes, Argentina, Ross (1995) found $\mathrm{C}$. saltanensis for the first time while capturing adult Culicidae. In a study on the coexistence of Culicidae species in artificial breeding sites in northern Paraná, LOPES (1997b) found larvae of Culex bahamensis Dyar \& Knab, 1906 in water reservoirs and in troughs. These specimens were then identified as C. bahamensis, but now they are known as C. saltanensis (Lopes, personal information). Therefore, the morphometric knowledge of this mosquito's different stages of development is important because of its colonization potential in urban areas and because it competes with $\mathrm{C}$. quinquefasciatus.

Micrometric oculars were used to conduct the anatomic measurement of variations in form and to establish standard measurement means of structures in a given stage of animal life. Anatomic measurements are also useful to separate cryp- 
tic species based on anatomical structures, allowing for a better understanding of the morpho-physiological and ecological adaptations of organisms to the environment.

Studies based on anatomic measurements of Culicidae are rare. Nonetheless, NAYAR \& SAUERMAN (1970) measured adults to evaluate the effect of larvae density, diet variations, and salinity on morphology. Jupp (1987) measured both immatureand adult Culicidae to separate individuals of the same species of Culex (Culex) pipiens, from two sites.

This study used mean anatomical measurements to understand the intraspecific morphometric variations of eggs and immature forms of $C$. saltanensis. M ean measurements were used to define patterns for identification of instars and patterns of size and features of eggs, and to assess numerical variations of instars in relation to the Culex Linnaeus, 1758 genus pattern.

\section{MATERIAL AND METHODS}

Culex saltanensis were reared in a $50 \times 40 \times 40 \mathrm{~cm}$ cage, where pupas were introduced every 15 days. The pupas were obtained from eggs collected in the effluent treatment ponds of a soft drink factory in Londrina, Paraná, Brazil. Adults were fed daily on a sugar solution at $12 \%$ and on quail blood [Coturnix japonica, Tinamidae (Temminck \& Schlegel, 1849)]. C. japonica was kept immobilized in a cage $(16 \times 10 \times 6 \mathrm{~cm})$ with $1.5 \mathrm{~cm}$ wire mesh. The cage was put inside the insect breeder three times a week, after twilight, for about three hours.

Eggs obtained in the laboratory were either individually placed in $40 \mathrm{~mL}$ flasks or kept altogether in $600 \mathrm{~mL}$ polyethylene pots, and were stored in an acclimatized chamber (BOD) at $27 \pm 1$ 으 $\mathrm{C}$ and $14 \mathrm{~L}: 10 \mathrm{D}$ photoperiod. Chamber conditions were similar to the summer weather in Londrina. Larvae were fed daily with 20 mg of "Dog Show", a kind of puppy food, ground into one-millimeter particles.

Measurements of anatomical structures in different instars were normally taken one day after the cuticle changed, except for the first instar. In this case, measurements were taken soon after hatching and were repeated 48 hours later. In the spring and summer of 1999, 50 immature specimens and eggs laid in the laboratory, in addition to 50 larvae collected in the field 48 hours after hatching were used for each measurement. The larvae collected on the field and in the laboratory that had started the measurement series were immersed in alcohol (70\%) and were placed between glass slides containing Hoyer liquid. A stereoscopic microscope with a $10 \times$ micrometric ocular and $6.3 \times$ objective lenses were used for measuring the larvae.

Siphon length of immature specimens was measured from base to apex, whereas siphon width was measured at the base, at the insertion, and at the eighth abdominal segment (Fig. 1). Cephalic capsule length was measured from one head extremity to the other, and width was measured between the two eye extremities (Fig. 1). A digital electronic micrometer caliper (STARRETT, series 727) was used to transform all measures into millimeters.

Revista Brasileira de Zoologia 24 (1): 169-174, março 2007

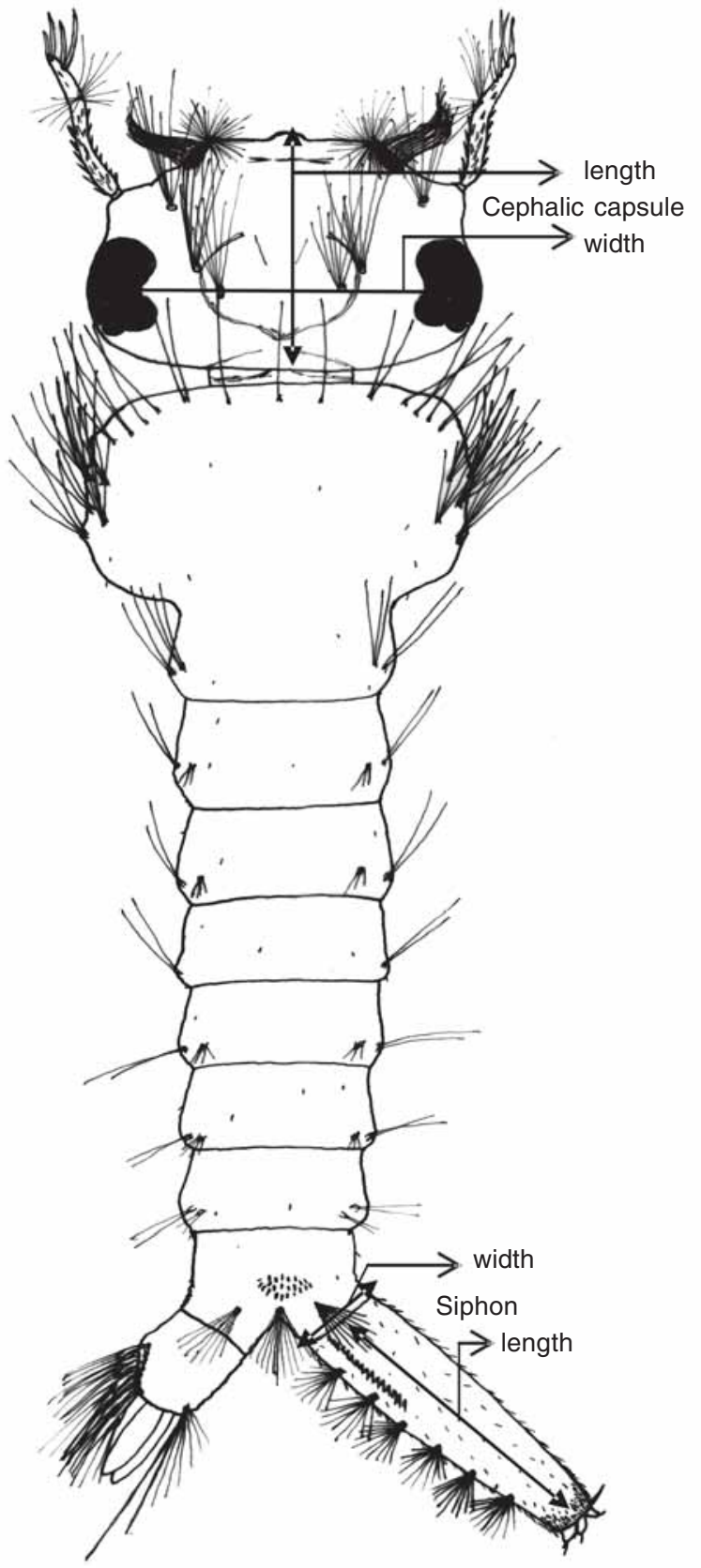

Figure 1. Larvae of $C$. saltanensis showing structures and extension where anatomical measurements were made

Forth instar larvae collected on the field were anatomically compared to immature specimens of $4^{\text {th }}$ instar bred in the laboratory. Recently hatched $1^{\text {st }}$ instar larvae in laboratory were compared to late $1^{\text {st }}$ instar larvae after 48 hours.

Laboratory and field egg length was assessed before larvae hatching, whereas opercula were measured after hatching.

Culex saltanensis and C. quinquefasciatus occurred simul- 
taneously and constantly on the field breeding site. Therefore, it became necessary to separate the two species, during the egg phase, to observe morphological aspects such as raft egg and chorion pigmentation.

Data were submitted to calculations of the arithmetic mean, standard deviation, analysis of variance complemented by the Tukey test at $5 \%$ significance level, and linear regression (VANZOLINI 1993).

Some of the biological material used for this study is stored in the Laboratório de Entomologia do Centro de Ciências Biológicas at the Universidade Estadual de Londrina, Paraná.

\section{RESULTS AND DISCUSSION}

The length and opercula size of eggs laid on the field and in the laboratory did not differ (Tabs I and V).

Although C. saltanensis can have several hosts, LouREnçoDE-OliveIRA \& HEYDEN (1986) consider it mainly ornithophilous. C. japonica (quail) blood, the only feed for females bred in laboratories, did not affect egg size pattern when compared to females coming from fields where they had wide access to different blood sources. Therefore, we may assume that either blood type does not affect egg size, or C. saltanensis is strongly ornitho- philous in northern Paraná. Consequently, blood type did not explain the absence of differences in egg size, and further studies are needed.

Larval growth of $C$. saltanensis occurred without exuviate change in the first instar, at $27 \pm 1{ }^{\circ} \mathrm{C}$ and $14 \mathrm{~L}: 10 \mathrm{D}$ photoperiod. This observation was made after comparing recently hatched, $1^{\text {st }}$ instar immature specimens 48 hours later (Tab. II). Immature specimens differed in siphon length and cephalic capsule size (Tabs II and V). Anatomical structures means were larger for late $1^{\text {st }}$ instar larvae (48 hours) (Tab. II).

According to SeRvice (1993), cuticle deposition rate, in some species, depends on temperature and ultraviolet light. In each instar, the continuous larval growth of mosquitoes can be observed by the progressive increases in body size, in areas covered with thin cuticle layers (CLEMENTS 1992).

The $4^{\text {th }}$ instar immature specimens obtained on the field and in the laboratory had measurable differences in siphon width and in width and length of the cephalic capsule. In all structures, the larvae obtained in the laboratory had the highest means but siphon length. (Tab. III).

Larger mean sizes among laboratory larvae (Tabs III and V) may have been influenced by the food ("Dog Show") given

Table I. Length $(\mathrm{mm})$ of $\mathrm{C}$. saltanensis eggs and opercula from laboratory and field.

\begin{tabular}{|c|c|c|c|c|c|c|c|c|}
\hline \multirow{2}{*}{ Structures } & \multicolumn{4}{|c|}{ Field $(n=50)$} & \multicolumn{4}{|c|}{ Laboratory $(n=50)$} \\
\hline & Max. & Min. & Average & S.D. & Max. & Min. & Average & S.D. \\
\hline Egg length & 0.733 & 0.671 & 0.709 & 0.013 & 0.796 & 0.577 & 0.706 & 0.054 \\
\hline Opercula length & 0.234 & 0.156 & 0.199 & 0.019 & 0.234 & 0.156 & 0.202 & 0.014 \\
\hline
\end{tabular}

Table II. Length and width ( $\mathrm{mm}$ ) of siphon and cephalic capsules of recent ( 0 hours) and late hatching (after 48 hours) of $1^{\mathrm{s}}$ instar larvae of $C$. saltanensis, $n=50$.

\begin{tabular}{|c|c|c|c|c|c|c|c|c|}
\hline \multirow{2}{*}{ Structures } & \multicolumn{4}{|c|}{ Recent hatching (0 hours) } & \multicolumn{4}{|c|}{ Late hatching (48 hours) } \\
\hline & Max. & Min. & Average & S.D. & Max. & Min. & Average & S.D. \\
\hline Siphon length & 0.156 & 0.078 & 0.115 & 0.018 & 0.343 & 0.140 & 0.236 & 0.038 \\
\hline Siphon width & 0.094 & 0.047 & 0.068 & 0.012 & 0.125 & 0.062 & 0.093 & 0.015 \\
\hline Cephalic capsule length & 0.218 & 0.109 & 0.168 & 0.031 & 0.250 & 0.156 & 0.219 & 0.019 \\
\hline Cephalic capsule width & 0.281 & 0.187 & 0.243 & 0.020 & 0.328 & 0.203 & 0.288 & 0.027 \\
\hline
\end{tabular}

Table III. Length and width $(\mathrm{mm})$ of siphon and cephalic capsules of $4^{\text {th }}$ instar $\mathrm{C}$. saltanensis larvae obtained in the laboratory and on the field, $\mathrm{n}=50$.

\begin{tabular}{|c|c|c|c|c|c|c|c|c|}
\hline \multirow{2}{*}{ Structures } & \multicolumn{4}{|c|}{ Field } & \multicolumn{4}{|c|}{ Laboratory } \\
\hline & Max. & Min. & Average & S.D. & Max. & Min. & Average & S.D. \\
\hline Siphon length & 1.482 & 1.248 & 1.372 & 0.058 & 1.482 & 1.248 & 1.366 & 0.050 \\
\hline Siphon width & 0.359 & 0.234 & 0.297 & 0.028 & 0.406 & 0.250 & 0.336 & 0.042 \\
\hline Cephalic capsule length & 0.702 & 0.468 & 0.593 & 0.046 & 0.733 & 0.515 & 0.661 & 0.050 \\
\hline Cephalic capsule width & 1.404 & 0.905 & 1.095 & 0.069 & 1.217 & 1.014 & 1.143 & 0.041 \\
\hline
\end{tabular}


to immature specimens. The dog food provided contained most of the 10 aminoacids and lipids ideally needed for larval development. Without these nutrients, the larvae would not have survived the third instar, particularly due to the lack of cholesterol, cephalin, and lecithin, which are particularly important for them (Consoli \& LouREnço-De-Oliveira 1998).

When in natural environments, larvaefeed indistinctively on the habitat microplankton made of rotifers, bacteria, fungi spores, and other particles of organic matter. Nevertheless, occasional nutritional deficiency may either extend development time of immature specimens, or increase mortality during the adult transition phase (BERGo et al. 1990).

Larvae comparison of first, second, third, and forth instars showed a linear increase in size for all analyzed structures (Fig. 2). Morphometry is, therefore, an efficient method to determine larvae developmental stages (Tab. IV). Morphometric
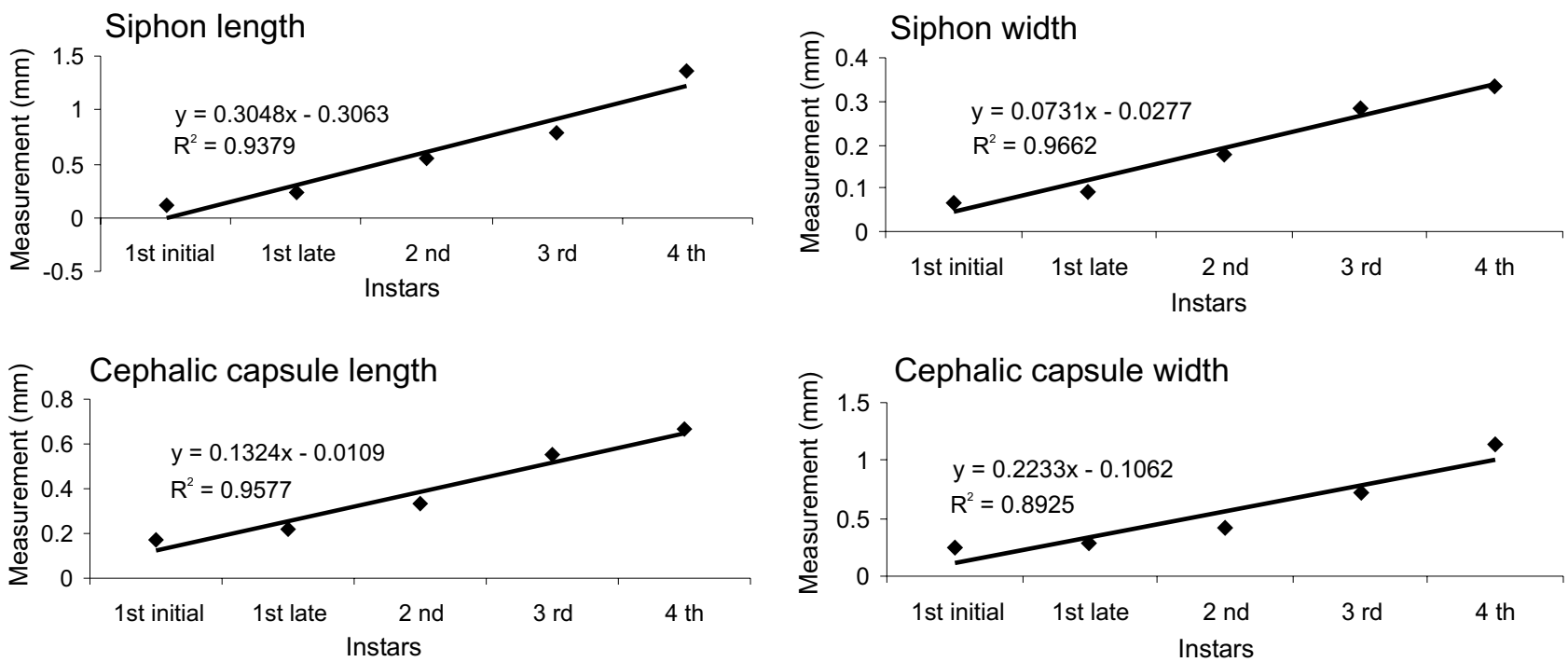

Figure 2. Anatomical structure of C. saltanensis obtained in the laboratory, 24 hours after instar change, and linear correlation.

Table IV. Length and width (in $\mathrm{mm}$ ) of C. saltanensis siphon and cephalic capsule in all immature instars bred in the laboratory, $\mathrm{n}=50$.

\begin{tabular}{clcccc}
\hline \multirow{2}{*}{ Instars } & \multicolumn{5}{c}{ Structures } \\
\cline { 2 - 6 } $1^{\text {st }}(48 \mathrm{~h})$ & Siphon length & Siphon width & Cephalic capsule length & Cephalic capsule width \\
\cline { 2 - 6 } & Max. & 0.34 & 0.13 & 0.25 & 0.33 \\
& Min. & 0.14 & 0.06 & 0.16 & 0.20 \\
& Average & 0.24 & 0.09 & 0.22 & 0.29 \\
& S.D. & 0.04 & 0.02 & 0.02 & 0.03 \\
$2^{\text {nd }}$ & Max. & 0.62 & 0.27 & 0.39 & 0.50 \\
& Min. & 0.47 & 0.13 & 0.27 & 0.31 \\
& Average & 0.54 & 0.18 & 0.33 & 0.42 \\
$3^{\text {rd }}$ & S.D. & 0.04 & 0.03 & 0.03 & 0.04 \\
& Max. & 0.86 & 0.33 & 0.62 & 0.78 \\
& Min. & 0.70 & 0.23 & 0.47 & 0.62 \\
& Average & 0.78 & 0.29 & 0.55 & 0.72 \\
$4^{\text {th }}$ & S.D. & 0.03 & 0.03 & 0.03 & 0.04 \\
& Max. & 1.48 & 0.41 & 0.73 & 1.22 \\
& Min. & 1.25 & 0.25 & 0.52 & 1.01 \\
& Average & 1.37 & 0.34 & 0.66 & 1.14 \\
& S.D. & 0.05 & 0.04 & 0.05 & 0.04 \\
\end{tabular}

Revista Brasileira de Zoologia 24 (1): 169-174, março 2007 


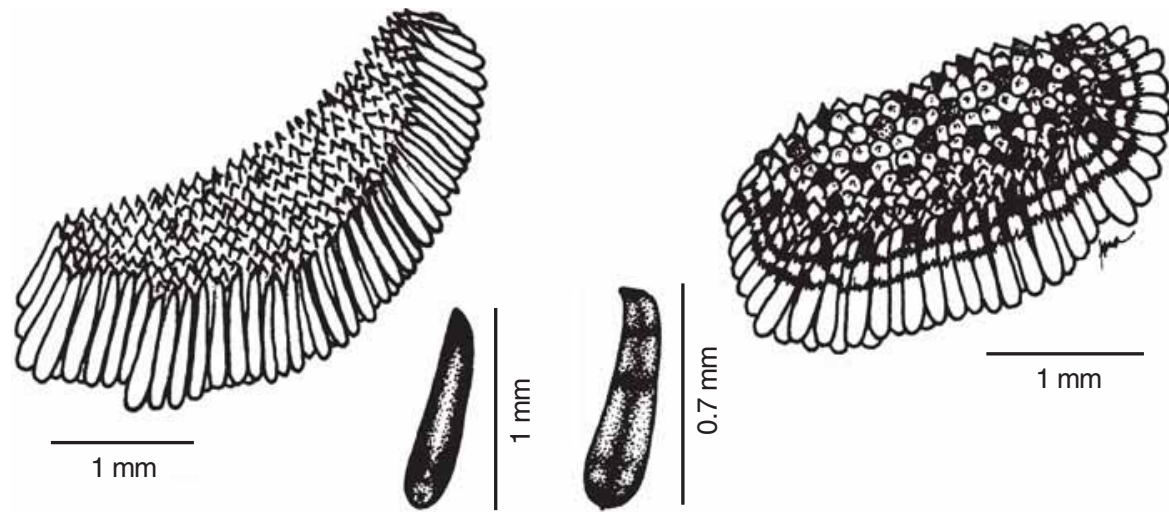

Figure 3. Comparison of egg rafts and general egg aspect C. quinquefasciatus (left) and C. saltanensis (right).

Table V. Measurements $(\mathrm{mm})$ of anatomical structures of C. saltanensis, from the egg phase (eggs and opercula length) to the larval last instar (siphon length, siphon width, cephalic capsule length and width).

\begin{tabular}{|c|c|c|c|c|c|c|}
\hline Larval and egg stages & Siphon length & Siphon width & Cephalic capsule length & Cephalic capsule width & Egg length & Opercula length \\
\hline Laboratory $4^{\text {th }}$ instar & $1.3658 * A$ & $0.3358 \mathrm{~A}$ & $0.6664 \mathrm{~A}$ & $1.1426 \mathrm{~A}$ & & \\
\hline Field $4^{\text {th }}$ instar & $1.3704 \mathrm{~A}$ & 0.2968 B & $0.5930 \mathrm{~B}$ & $1.0954 \mathrm{~B}$ & & \\
\hline Laboratory $3^{\text {rd }}$ instar & $0.7816 \mathrm{~B}$ & $0.2854 \mathrm{~B}$ & $0.5480 \mathrm{C}$ & $0.7208 \mathrm{C}$ & & \\
\hline Laboratory $2^{\text {nd }}$ instar & $0.5422 \mathrm{C}$ & $0.1792 \mathrm{C}$ & $0.3298 \mathrm{D}$ & $0.4238 \mathrm{D}$ & & \\
\hline Laboratory Late $1^{\text {st }}$ instar & $0.2362 \mathrm{D}$ & $0.0904 \mathrm{D}$ & $0.2190 \mathrm{E}$ & $0.2878 \mathrm{E}$ & & \\
\hline Recent hatching $1^{\text {st }}$ instar & $0.1146 \mathrm{E}$ & $0.0676 \mathrm{D}$ & $0.1688 \mathrm{~F}$ & $0.2428 \mathrm{~F}$ & & \\
\hline Field eggs & & & & & $0.7090 \mathrm{~A}$ & $0.1988 \mathrm{~A}$ \\
\hline Laboratory eggs & & & & & $0.7038 \mathrm{~A}$ & $0.2020 \mathrm{~A}$ \\
\hline DMS & 0.0362 & 0.0299 & 0.0364 & 0.0389 & 0.0588 & 0.0129 \\
\hline CV \% & 2.52 & 7.30 & 4.43 & 3.05 & 5.71 & 4.41 \\
\hline
\end{tabular}

*Original data. Means followed by the same letter in the column do not differ, according to the Tukey test at $5 \%$ significance level.

differences among parts with thicker sclerotization, such as the cephalic capsule and the breathing siphon, were due to the increase in size immediately after ecdysis. This is a manifestation of insect growth (CLEMENTS 1992), which has also occurred in our study.

When all analyzed structures were compared within each instar, the Tukey test showed the same siphon length only among the fourth instar field and laboratory larvae (Tab. V). Siphon width structures showed no differences among paired larvae of first instar recently hatched, first instar that hatched late, fourth instar obtained on the field, and third instar obtained in the laboratory. Larvae cephalic capsule differed in length and width in all instars (Tab. V). Second and $3^{\text {rd }}$ instar larvae differed in all of the structures analyzed (Tab. IV).

Cephalic capsule measures showed significant differences in all phases of larval development and may be considered the most important parameter for the separation of larval instars.

In this study, the species C. quinquefasciatus and C. saltanensis had to be separated from each other, preferably in the egg stage, because they were frequently found in the same habitat. Differently from C. quinquefasciatus, C. saltanensis eggs had a metallic pigmentation normally halfway the egg length and the larger overall egg width. On the other hand, C. quinquefasciatus chorion is flat and more filiform than C. saltanenis (Fig. 3). C. saltanensis eggs develop rafts that are more oval than rafts developed by C. quinquefasciatus, which are more filiform (Fig. 3).

\section{ACKNOWLEDGMENTS}

We thank Fabrício Baccaro, Paulo Cypriano and Emerson Martins from the Universidade Estadual de Londrina, for providing the $C$. saltanensis larvae.

\section{REFERENCES}

Bergo, E.S.; G.M. Buralli; J.L.F. Santos \& S.M. Gurgel. 1990. Avaliação do desenvolvimento larval de Anopheles darlingi criado em laboratório sob diferentes dietas. Revista de Saúde Pública 24: 95-100.

Revista Brasileira de Zoologia 24 (1): 169-174, março 2007 
Clements, A.N. 1992. The biology of mosquitoes. London, Chapman \& Hall, vol.1, XXIII+509p.

Consoli, R.A.G.B. \& R. Lourenço-de-Oliveira. 1998. Principais mosquitos de importância sanitária no Brasil. Rio de Janeiro, Fiocruz, 228p.

JuPP, P.G. 1987. Comparative studies on morphology and laboratory biology of Culex (Culex) pipiens Linnaeus (Diptera: Culicidae) from South Africa and England. Journal of the Entomological Society of South Africa 50: 445-461.

LoPES, J. 1997a. Ecologia de mosquitos (Diptera, Culicidae) em criadouros naturais e artificiais de área rural do norte do estado do Paraná, Brasil. VI. Coletas de larvas no peridomicílio. Revista Brasileira de Zoologia 14: 571-578.

LoPES, J. 1997b. Ecologia de Mosquitos (Diptera, Culicidae) em criadouros naturais e artificiais de área rural do norte do estado do Paraná, Brasil. VII. Coexistência das espécies. Iheringia Série Zoologia 83: 91-97.

LOURENÇO-DE-OlIVEIRA, R. 1984. Alguns aspectos da ecologia dos mosquitos (Diptera: Culicidae de uma área de planície (Granjas Calábria), em Jacarepaguá, Rio de Janeiro. I. Freqüência comparativa das espécies em diferentes ambientes e métodos de coleta. Memórias do Instituto Oswaldo Cruz 79: 479-490.

Lourenço-de-Oliveira, R. \& F.A. De CAstro. 1991. Culex saltanensis
Dyar,1928. Natural vector of Plasmodium juxtanucleare in Rio de Janeiro, Brasil. Memórias do Instituto Oswaldo Cruz 86: 87-94.

Lourenço-de-Oliveira, R. \& R. Heyden. 1986. Alguns aspectos da ecologia dos mosquitos (Diptera: Culicidae), de uma área de planície (Granjas Calábria), em Jacarepaguá, Rio de Janeiro. IV. Preferências alimentares quanto ao hospedeiro e freqüência domiciliar. Memórias do Instituto Oswaldo Cruz 81: 15-27.

NAYAR, J.K. \& J.R. SAUERMAN. 1970. A comparativestudy of growth and development in Florida mosquitoes. Journal of Medical Entomology 7: 521-528.

Rossı, G.C. 1995. Culicidios nuevos para las provincias de Entre Rios y Corrientes. Revista de la Sociedad Entomológica Argentina 54: 97-98.

Service, M.W. 1993. Mosquito ecology field sampling methods. Londron, Chapman \& Hall, $2^{\text {nd }}$ ed., XII+988p.

Sibajev, A.; R.S. Pacheco; M.J. Soraes; E. Cupolillo; E.A.B. dos SanTOS \& H. Momen. 1993. Crithidia ricardoi a new species of trypanossomatidae isolated from Culex saltanensis Dyar, 1928 (Diptera, Culicidae). Memórias do Instituto Oswaldo Cruz 88: $541-545$.

VANZOLINI, P.E. 1993. Métodos estatísticos elementares em sistemática zoológica. São Paulo, Hucitec, VII+130p.

Received in 07.VII.2006; accepted in 05.III.2007.

Revista Brasileira de Zoologia 24 (1): 169-174, março 2007 